\title{
Amorphous Sediment Measurement
}

National Cancer Institute

\section{Source}

National Cancer Institute. Amorphous Sediment Measurement. NCI Thesaurus. Code C74666.

The determination of the amount of amorphous sediment present in a sample. 